\title{
Unusual Cytoplasmic Inclusions Induced in Tobacco by Peanut Stunt Virus Subgroup II Strains Map to RNA3
}

\author{
Margaret Sanger, Ulla E. Järlfors, and Said A. Ghabrial
}

Department of Plant Pathology, University of Kentucky, Lexington 40546-0091.

Accepted for publication 29 July 1998.

\begin{abstract}
Sanger, M., Järlfors, U. E., and Ghabrial, S. A. 1998. Unusual cytoplasmic inclusions induced in tobacco by peanut stunt virus subgroup II strains map to RNA3. Phytopathology 88:1192-1199.

Infection of tobacco protoplasts or leaf tissues with peanut stunt virus (PSV) subgroup II strains induced the production of unusual cytoplasmic ribbon-like inclusions. The inclusion structures appeared as long, thin, densely staining sheets that were prevalent within the cytoplasm, accumulating most commonly near vacuoles. Numerous virions and ribosomes could be seen adjacent to the inclusion surfaces. The formation of these novel inclusions appeared to be subgroup specific, since infection of to-

J (subgroup I), induced the inclusions. Furthermore, inclusion formation was shown to be host specific, because the inclusions were not detected in either of two leguminous host species infected with PSV subgroup II strains. Using tobacco protoplasts electroporated with various assortments of infectious RNA transcripts derived from cDNA clones of genomic RNAs of PSV-ER and PSV-W, we demonstrated that induction of the unusual ribbon-like inclusions maps to PSV-W (subgroup II) RNA3. This conclusion is consistent with the finding that PSV strain BV-15, a natural intraspecific reassortant that derives its RNA2 and RNA3 from a subgroup I strain, did not induce inclusion formation.
\end{abstract} bacco with PSV strains W and B (subgroup II), but not strains ER, V, and
Additional keywords: reassortment, ultrastructure.
Peanut stunt virus (PSV) is a member of the genus Cucumovirus in the family Bromoviridae (23). Other members of the genus are tomato aspermy virus (TAV) and the type member cucumber mosaic virus (CMV). Published reports on ultrastructural changes in PSVinfected plants are very limited, and the observed changes have been similar to those induced by other cucumoviruses (17). Major ultrastructural consequences of cucumovirus infections include extensive secondary vacuolation resulting in fragmentation of cytoplasm and proliferation of endomembranes (17). Cytoplasmic and intravacuolar crystalline inclusions have been reported more regularly in conjunction with CMV infections than with TAV and PSV infections (17). Although crystalline inclusions of PSV particles within the cytoplasm and vacuoles have been recorded, aggregates of virus particles within the cytoplasm have been more frequently observed $(12,13,15,16)$.

PSV is an economically important pathogen of legumes worldwide $(18,26)$. Like other cucumoviruses, PSV has a tripartite genome of positive-strand RNAs, designated RNA1, RNA2, and RNA3 in order of decreasing size, that are packaged in isometric particles of about $28 \mathrm{~nm}$ in diameter. RNA1 and RNA2 encode the 1a and 2a proteins, respectively, that along with host components are required for replication. RNA3 is dicistronic and encodes a movement protein (MP) and a coat protein (CP), which is expressed from subgenomic RNA4 (21). RNA4 is packaged together with RNA3. A small overlapping gene, $2 \mathrm{~b}$, encoded by RNA2, is present in all cucumoviruses sequenced to date and is most likely expressed through the subgenomic mRNA RNA4A (7). Strains of PSV have been classified into two major subgroups (I and II) based on serology and percent nucleotide (nt) sequence identity $(9,11)$. Furthermore, a naturally occurring reassortant (PSV-BV-15) between the two subgroups has been reported and characterized at the molecular level $(10,19)$.

Corresponding author: S. A. Ghabrial; E-mail address: saghab00@ukcc.uky.edu

Publication no. P-1998-0910-02R

(C) 1998 The American Phytopathological Society
In this paper, we describe novel ribbon-like inclusions that are produced in tobacco in response to infection with PSV subgroup II strains, and we present molecular genetic evidence that the formation of the unusual inclusions maps to RNA3.

\section{MATERIALS AND METHODS}

Virus strains, host plants, and antisera production. The sources of PSV strains ER, J, V, BV-15, W, and B were as described previously $(9,10,19)$. All PSV strains were maintained in cowpea (Vigna unguiculata (L.) Walp. 'Blackeye') and increased in Burley tobacco (Nicotiana tabacum L. 'Kentucky 14') or in cowpea. Purification of PSV virions was as described by Ghabrial et al. (8). Viruses were stored as purified RNAs at $-80^{\circ} \mathrm{C}$. Host plant species used for electron microscopy studies were Burley tobacco, 'Blackeye' cowpea, and bean (Phaseolus vulgaris L. 'Pinto').

Immunoglobulin $\mathrm{G}$ ( $\mathrm{IgG}$ ) purified from a rabbit antiserum produced against glutaraldehyde-stabilized PSV-W virions was previously described (9). Goat anti-rabbit IgG conjugated with $15 \mathrm{~nm}$ of colloidal gold particles was produced by Aurion Immunogold Reagents and Accessories (Wageningen, the Netherlands) and obtained through Electron Microscopy Sciences (Fort Washington, PA).

Plasmids. Recombinant plasmids containing full-length cDNA clones of the genomic RNAs of PSV-W (plasmids pW1, pW2, and pW3) and PSV-ER (plasmids pER1, pER2, and pER3) were previously described (11). Infectious transcripts generated from these cDNA clones (11) were used to produce pseudorecombinants (artificial reassortants) encompassing all possible combinations of transcripts representing the genomic RNAs of the two strains. Plasmids pER3-3' and pW3 1 1 (11) were used to generate probes specific to PSV strains ER and W, respectively.

Preparation and electroporation of protoplasts. Protoplasts were prepared from cultured tobacco suspension cells (Nicotiana tabacum 'Xanthi nc') as per Passmore et al. (22). Procedures for protoplast electroporation and for extraction and analysis of cellular RNA from electroporated protoplasts were described by $\mathrm{Hu}$ et al. (11). 
Electron microscopy and immunogold labeling. Protoplast samples (approximately $2 \times 10^{5}$ ) were prepared for electron microscopy using a modification of the methods of Anjos et al. (1). Protoplasts were collected by centrifugation, resuspended in the fixative (4\% glutaraldehyde in $0.2 \mathrm{M}$ cacodylate buffer, $\mathrm{pH} 7$ ), and kept at room temperature for $1 \mathrm{~h}$. Following a brief rinse in the cacodylate buffer, the samples were resuspended in a second fixative $\left(1 \% \mathrm{OsO}_{4}\right.$ in $0.1 \mathrm{M}$ cacodylate buffer, $\left.\mathrm{pH} 7\right)$ and kept at $4{ }^{\circ} \mathrm{C}$ for $30 \mathrm{~min}$. After fixation, the samples were rinsed several times in water to remove all traces of buffer, suspended in aqueous uranyl acetate, and kept overnight at room temperature. A series of ethanol dehydration steps were followed by treatment with $100 \%$ acetone and embedding in Spurr's medium (24). Polymerization took place overnight at $70^{\circ} \mathrm{C}$. Leaf tissues were processed in solutions prepared in the same way as for the protoplasts, but fixation times were doubled. Thin sections (approximately $90 \mu \mathrm{m}$ ) were cut with a diamond knife on an LKB III Ultratome (LKB Instruments Inc., Rockville, MD) and stained with lead citrate. Stained sections were viewed in a Philips 400 electron microscope (N. V. Philips Gloeilampenfabrieken, Eindhoven, the Netherlands).
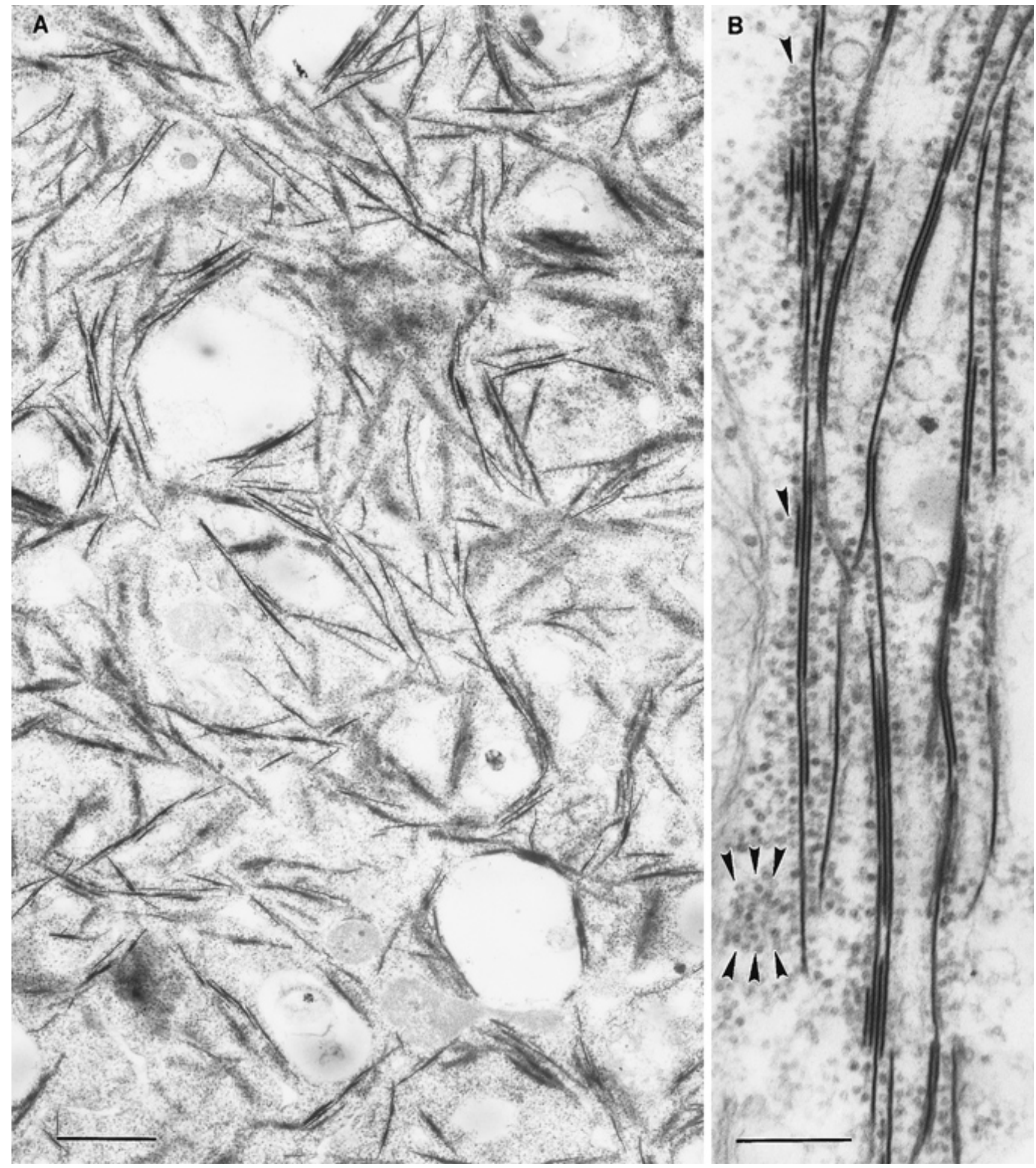

Fig. 1. Electron micrographs of thin sections of tobacco protoplasts infected via electroporation with viral RNA extracted from purified peanut stunt virus strain W virions. Protoplasts were prepared for electron microscopy 4 days postelectroporation. A, A thin section of a tobacco protoplast containing numerous densely staining inclusions. Bar $=1,000 \mathrm{~nm}$. B, A cross section at a higher magnification of the inclusion structures. Note the presence of numerous virus-like particles occurring singly or in aggregates (arrowheads) adjacent to the inclusion surfaces. Bar $=250 \mathrm{~nm}$. 
Immunogold labeling was accomplished by a modification of the methods of Tomenius et al. (25). Protoplasts were fixed for $1 \mathrm{~h}$ in $0.1 \mathrm{M}$ cacodylate buffer, $\mathrm{pH} 7$, containing $2 \%$ paraformaldehyde and $1 \%$ glutaraldehyde. The samples were then dehydrated through $80 \%$ ethanol, embedded in London resin white, and allowed to polymerize overnight at $53^{\circ} \mathrm{C}(20)$. For gold labeling, the grids supporting the thin sections were left floating on the blocking solution ( $2 \%$ bovine serum albumin in TBST: $20 \mathrm{mM}$ Tris- $\mathrm{HCl}, \mathrm{pH} \mathrm{7.4,}$ containing $150 \mathrm{mM} \mathrm{NaCl}, 0.1 \%$ bovine serum albumin, and $0.05 \%$ Tween 20) for $15 \mathrm{~min}$ at room temperature followed by incubation for $16 \mathrm{~h}$ with the primary antibody (rabbit IgG derived from an antiserum to PSV-W, $20 \mu \mathrm{g} / \mathrm{ml}$ ). The sections were then washed with TBST and incubated for $1 \mathrm{~h}$ with the secondary antibody (goat anti-rabbit IgG conjugated with $15 \mathrm{~nm}$ of gold particles, 1:25 in TBST). This was followed by washing with TBST and water and staining in uranyl acetate and lead citrate. Two types of controls were included. In one, sections from mock-inoculated protoplasts were subjected to the same labeling procedure, and in the second, sections from infected cells were treated with IgG from a preimmune serum instead of that derived from the PSV-W antiserum. All sections were examined in a Philips EM 400 electron microscope.

\section{RESULTS}

PSV-induced inclusions. Unusual cytoplasmic inclusions were observed in thin sections of tobacco protoplasts infected with PSV-W, a subgroup II strain (Fig. 1A and B). The inclusion structures appeared as long, thin, densely staining, ribbon-like sheets. The structures were prevalent within the cytoplasm and occurred either singly or stacked in small irregular groups (Fig. 1A). Numerous virus-like particles, either singly or clustered in small aggregates, could be seen adjacent to the surface of the structures (Fig. $1 \mathrm{~B}$, arrowheads). The ribbon-like nature of these inclusions becomes apparent when seen at high magnification and in oblique configuration (Fig. 2). The length of the ribbon-like inclusions was variable and may exceed $1 \mu \mathrm{m}$, but the structures appeared to be of uniform width (50 to $70 \mathrm{~nm}$ ) and thickness (about 8 to $12 \mathrm{~nm}$ ). The ribbon-like inclusions were also observed in PSV-W-inoculated and systemically infected tobacco leaf tissue, accumulating most commonly near vacuoles within the cytoplasm of mesophyll cells (Fig. 3A and B). These unusual inclusions were prevalent within the cytoplasm and did not appear to be present in other subcellular compartments. To determine whether PSV-W is unique in its ability to induce the formation of the unusual inclusions, another member of subgroup II, PSV-B $(5,9)$, was studied. The results indicated that PSV-B induced the formation of inclusions indistinguishable from those observed for PSV-W in both tobacco protoplasts and leaf tissue (data not shown). Thus, two members of PSV subgroup II strains induced the formation of the unusual ribbon-like inclusions in infected tobacco.

Effects of host species and virus strain on inclusion formation. When thin sections of PSV-W-infected 'Pinto' bean or cowpea leaf tissue were examined, no ribbon-like inclusions were observed. Clusters or aggregates of virus-like particles, however, were noted within the cytoplasm (data not shown). Similar results were observed for 'Pinto' bean infected with PSV-B. No crystalline inclusions similar to those observed with subgroup I strains were detected (discussed below). Our examination, however, was focused on the detection of ribbon-like inclusions, and no exhaustive search for crystalline inclusions was made.

The formation of inclusions has also been examined in tobacco protoplasts and leaf tissues of cowpea, 'Pinto' bean, and tobacco infected with PSV-ER, a subgroup I strain. Protoplasts infected with two other subgroup I strains, PSV-J and PSV-V, were further included in this study. No ribbon-like inclusions were observed in any of the cells derived from material infected with the three subgroup I strains. Aggregates or crystalline inclusions of virus parti-
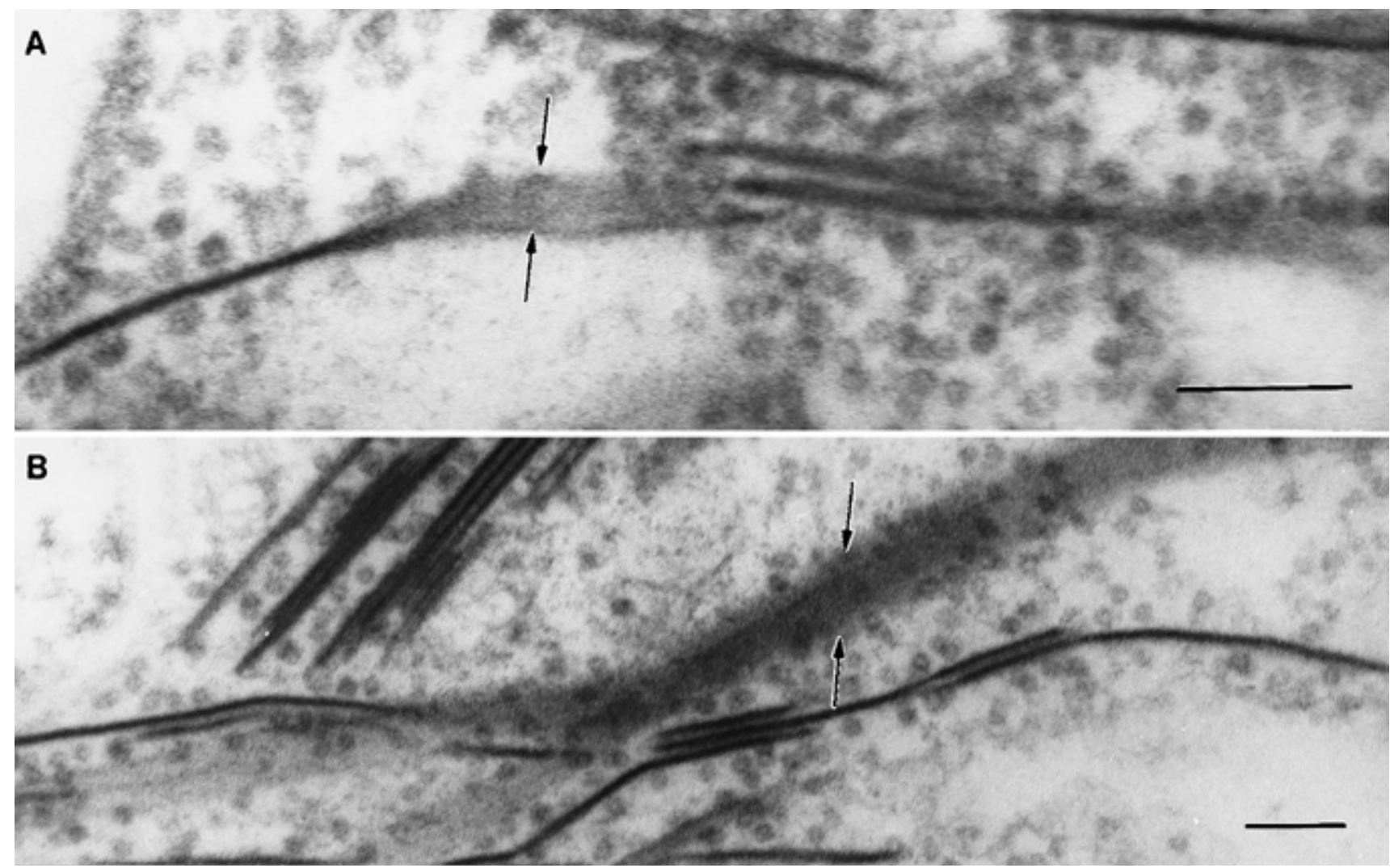

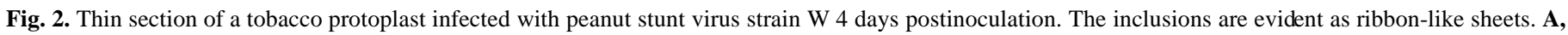

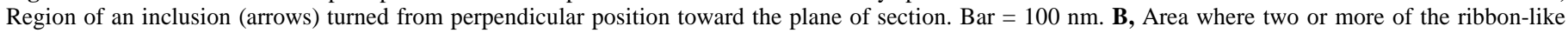
structures are superimposed (arrows). Bar $=100 \mathrm{~nm}$. 
cles, however, were observed (Fig. 4). The crystalline inclusions noted for all three strains were not as compact as those of some other isometric viruses (4) and exhibited gaps in the lattice structure, as has been reported for other cucumoviruses including PSV subgroup I strains (17). The crystalline inclusions tend to be associated with vacuoles. Another consequence of PSV infection that we have observed for all PSV strains examined, regardless of subgroup affiliation, is a high degree of secondary vacuolation and a moderate proliferation of endomembranes.

Composition of the ribbon-like inclusions. An antiserum specific to PSV-W virions was used to immunogold-label thin sections of tobacco protoplasts infected with PSV-W (Fig. 5A). Gold labeling was observed within the cytoplasm in association with viruslike particles and along the surface of the ribbon-like inclusions. We were unable to distinguish between labeling that may have been associated with viral particles adjacent to the surface of the ribbon-like inclusions and that may have been directly associated with the inclusions. Gold labeling detected in association with the ribbon-like inclusions was sparse, suggesting that the capsid protein is not likely to be a major constituent of the structures. Negligible gold labeling was detected in control thin sections treated with IgG from a preimmune serum (Fig. 5B).

Mapping viral sequence determinants of the unusual inclusions. The availability of infectious RNA transcripts derived from cDNA clones of the tripartite genomes of PSV strains ER and W and the observed differences between these two strains in their abilities to induce inclusion formation provided an opportunity to explore the genetic basis of inclusion induction by PSV. For this purpose, the eight different possible combinations of in vitro-synthesized RNA transcripts representing the genomes of PSV-W and

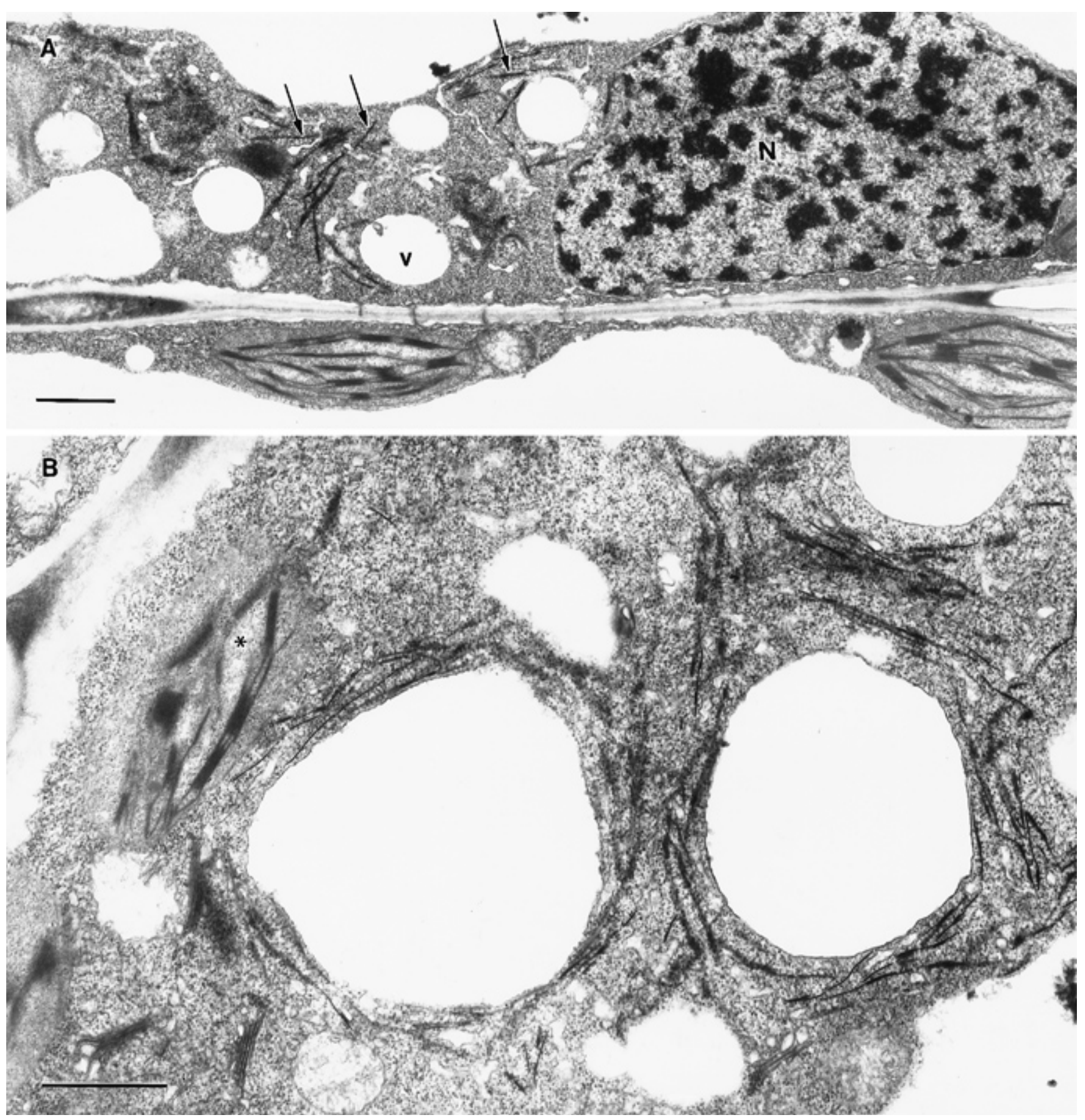

Fig. 3. Inclusion structures observed in a thin section of tobacco mesophyll tissue infected with peanut stunt virus strain W. A, Clusters of densely staining cytoplasmic inclusions are indicated by arrows. $\mathrm{v}=$ Secondary vacuole and $\mathrm{N}=$ nucleus. Bar $=1,000 \mathrm{~nm}$. B, Higher magnification image of inclusion structures accumulating around vacuoles. $*=$ chloroplast. $\mathrm{Bar}=1,000 \mathrm{~nm}$. 
PSV-ER were tested for their ability to replicate and induce the formation of the ribbon-like inclusions in tobacco protoplasts. All eight transcript sets were infectious and the predicted RNA species accumulated in tobacco protoplasts, yielding the expected hybridization pattern for each RNA combination (Fig. 6). Electron microscopic examination of thin sections of infected protoplasts revealed the presence of the ribbon-like inclusions in protoplasts electroporated with in vitro-synthesized RNA transcripts derived from PSV-W, as well as in all infections resulting from RNA transcript sets containing PSV-W RNA3 (Fig. 6). Infections resulting from inoculation with transcript sets that contained PSV-ER RNA3 did not display the ribbon-like inclusions characteristic of PSV-W. The source of RNA1 and RNA2, whether derived from PSV-ER or PSV-W, did not appear to affect inclusion formation (Fig. 6). Thus, subgroup II-derived RNA3 is essential for inducing the formation of ribbon-like inclusions in PSV-infected tobacco. With this in mind, we predicted that PSV strain BV-15, an intraspecific natural reassortant having RNA1 from a subgroup II strain, and RNA2 and RNA3, from a subgroup I strain $(9,10,19)$, would not induce inclusion formation. Results of an electron microscopic search for ribbon-like inclusions in thin sections of PSV-BV-15infected protoplasts were indeed negative. Aggregates of virus particles similar to those described for PSV-ER, however, were observed (data not shown).

\section{DISCUSSION}

The ribbon-like inclusions described in this study are novel structures not previously reported in association with virus infections. Cucumoviruses have been reported to induce the formation of cytoplasmic and intravacuolar crystalline viral inclusions with distinct morphology (17). The diagnostic value of these inclusions, however, is uncertain, because intracellular crystallization in association with cucumovirus infections is inconsistent. The ribbon-like inclusions that are prevalent in tobacco tissue infected with PSV subgroup II strains may provide a diagnostic means for differentiating PSV strain subgroups (discussed below).

The morphology and staining properties of the ribbon-like inclusions suggest that they are proteinaceous in nature. The results of our reassortment studies indicate that inclusion formation maps to RNA3 of PSV subgroup II strains. The finding that strain BV-15, an intraspecific natural reassortant having PSV subgroup II RNA1 and PSV subgroup I RNA2 and RNA3 $(9,10,19)$, does not induce inclusion formation is consistent with the conclusion that subgroup II-derived RNA3 is essential for inclusion production. This finding also lends support to the proposal that induction of the ribbon-like inclusions is subgroup specific, since subgroup I-derived RNA3 from four strains (PSV-ER, PSV-J, PSV-V, and PSV$\mathrm{BV}-15)$ was unable to induce inclusion formation.

Immunogold labeling of thin sections of PSV-W-infected tobacco protoplasts using an antiserum against PSV virions suggested that the CP is not a component of the inclusions. RNA3 is dicistronic and encodes two proteins, the 3 a protein and the CP. The PSV $3 \mathrm{a}$ protein, as well as those of all sequenced cucumoviruses, contains the principal conserved motif typical of the 30K MP superfamily (9). CMV 3a protein has been designated as an MP because it binds to single-stranded RNA, traffics itself and viral RNA from cell to cell, complements the movement of 3a gene-defective mutants of CMV in trans in transgenic plants expressing the 3a protein, associates with cell walls in infected plants, and has sequence and functional similarities to the MP of tobacco mosaic virus (2). By analogy to CMV, PSV 3a protein is designated as an MP.

Recent studies indicate that both the MP and $\mathrm{CP}$ are essential for cell-to-cell movement of CMV and favor the idea that CMV moves from cell to cell as a nucleoprotein transport complex rather than as virions $(2,6)$. MPs are known to interact with other viral gene products and with the viral genome and may facilitate trafficking of the genome transport complex through their interactions

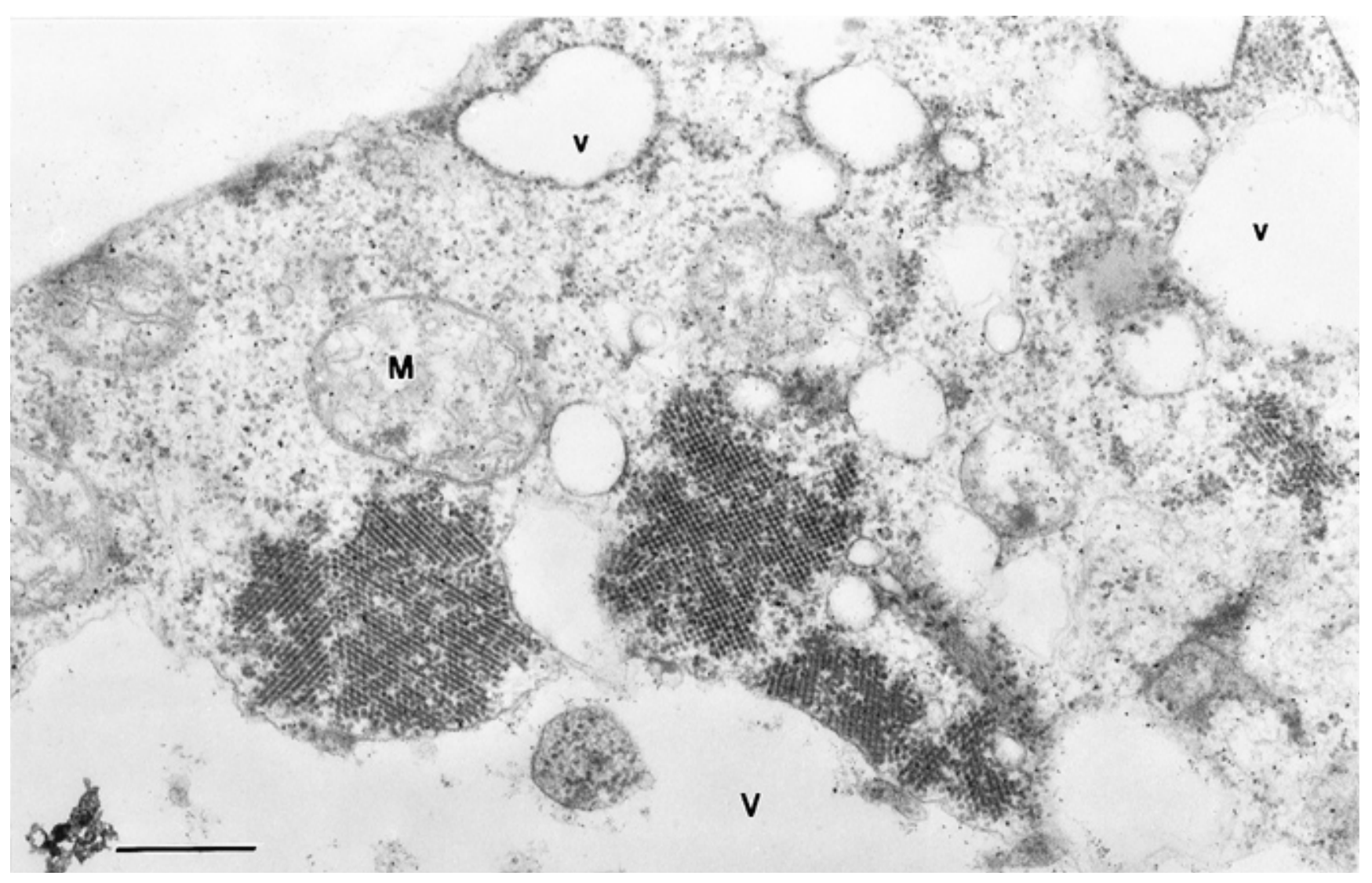

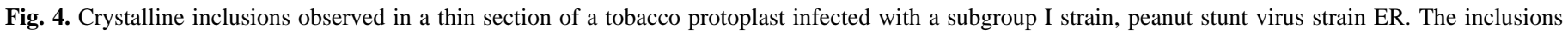
appear somewhat loosely packed within the cytoplasm, but associated with the vacuole $(\mathrm{V})$ and secondary vacuoles $(\mathrm{v})$. $\mathrm{M}=\mathrm{mitochondrion}$. Bar $=500 \mathrm{~nm}$. 
with the intracellular cytoskeleton trafficking system (3). We are currently investigating several possibilities to unravel the nature of the ribbon-like inclusions. These inclusions, which are formed in tobacco infected with PSV subgroup II strains, may be made up of the (i) MP alone, (ii) MP complexed to the viral genome or other viral gene products, or (iii) MP interacting with elements of the intracellular cytoskeleton trafficking system including molecular motors and other microtubule- and microfilament-associated pro-

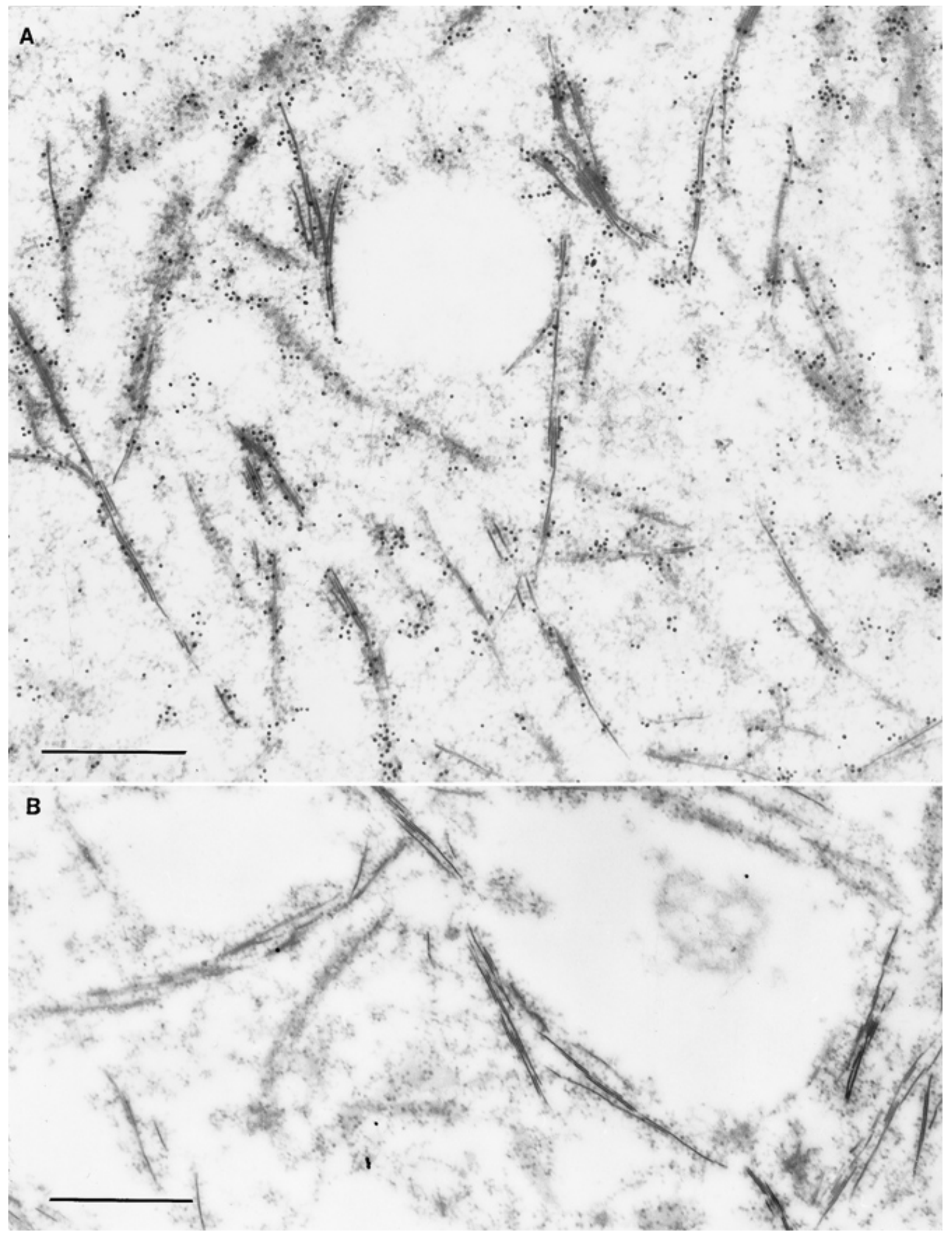

Fig. 5. A, Thin section of peanut stunt virus (PSV)-W-infected tobacco protoplast immunogold-labeled with immunoglobulin G (IgG) derived from an antiserum to PSV-W virions. Gold particles (approximately $15 \mathrm{~nm}$ ) are seen associated with virus-like particles within the cytoplasm. Sparse labeling may be seen along the inclusion surfaces. B, Control thin section of PSV-W-infected tobacco protoplast treated with IgG derived from a preimmune serum. Bar $=500 \mathrm{~nm}$. 
teins. Any of these interpretations must account for the fact that the ribbon-like inclusions are not formed in infections involving RNA3 derived from subgroup I strains and in host species other than tobacco. Production of antisera to bacterially expressed 1a, $2 \mathrm{a}$, and MP is underway for future use in immunogold-labeling studies of the inclusions.

It may be that the MP encoded by subgroup II strains, unlike that of subgroup I, accumulates to high levels in certain cellular compartments in tobacco. Examples of virus-induced structures in which the MP is the major component include the comovirus-induced tubular structures (14). Alternatively, subgroup II MPs may differ in their RNA- or protein-binding properties from those encoded by subgroup I, so that when complexed with viral-host components, the transport complex may become insoluble or locally concentrated in certain cellular environments. The inclusions, on the other hand, may be predominantly composed of host components, the formation of which is induced by subgroup II RNA3 or its gene products.

In conclusion, the experiments we have presented show that infection of tobacco protoplasts or leaf tissues with PSV subgroup II strains induces the production of unusual cytoplasmic ribbon-like inclusions and that the formation of these inclusions may be subgroup specific and host specific. Furthermore, using all possible

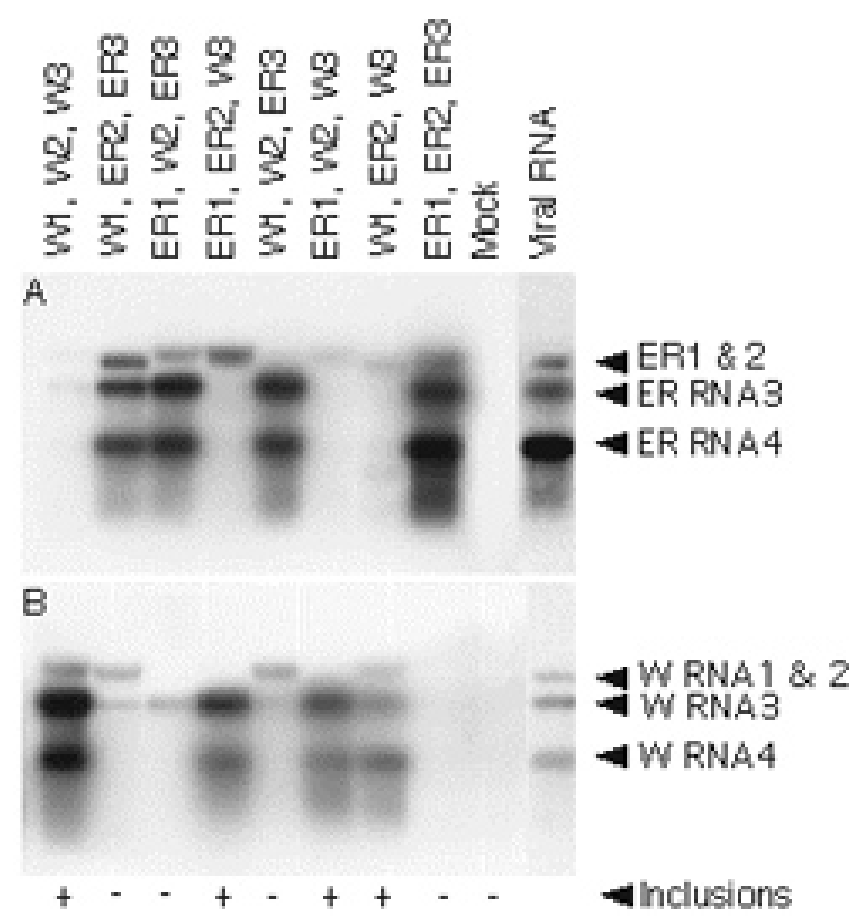

Fig. 6. Accumulation of peanut stunt virus (PSV) RNA in protoplasts electroporated with all possible combinations of infectious RNA transcript sets derived from PSV strains W and ER. Eight transcript sets were electroporated and the components of each set are indicated at the top of each lane (PSV-W RNA1 is designated as W1, PSV-W RNA2 as W2, and so on). Lane labeled "Mock" represents protoplasts electroporated with electroporation buffer alone and without RNAs. Nucleic acids extracted from protoplasts 4 days postelectroporation were denatured, analyzed by agarose gel electrophoresis, and blotted to nylon membranes. The resultant membranes were hybridized with ${ }^{32} \mathrm{P}$-labeled probes specific to A, PSV strain ER and B, PSV strain W. The lane labeled "Viral RNA" contains RNAs purified from A, PSV-ER virions and B, PSV-W. Migration positions of RNAs are indicated by arrows. The presence $(+)$ or absence $(-)$ of ribbon-like inclusions in protoplast samples electroporated with the various sets of infectious PSV transcripts is indicated at the bottom (Inclusions). The protoplast samples were encoded prior to fixation and were examined for the presence of inclusions in a "blind" test. In samples recorded as (+), inclusions were observed within the first 20 infected cells examined; in those recorded as $(-)$, inclusions were not observed after a minimum of 80 infected cells had been examined. The results shown are based on observations from two separate experiments. assortments of infectious RNA transcripts derived from the genomic RNAs of PSV-ER (subgroup I) and PSV-W (subgroup II), we demonstrated conclusively that induction of the unusual ribbonlike inclusions maps to PSV-W RNA3.

\section{ACKNOWLEDGMENTS}

This research was funded by a grant from The University of Kentucky Tobacco and Health Research Institute (5-41147) and is published as Journal Series Paper 98-12-67 of the Kentucky Agricultural Experiment Station. We thank R. G. Milne and C.-C. Hu for helpful discussion and valuable comments during the course of this study.

\section{LITERATURE CITED}

1. Anjos, R. J., Järlfors, U., and Ghabrial, S. A. 1992. Soybean mosaic potyvirus enhances the titer of two comoviruses in dually infected soybean plants. Phytopathology 82:1022-1027.

2. Canto, T., Prior, D. A., Hellwald, K. H., Oparka, K. J., and Palukaitis, P. 1997. Characterization of cucumber mosaic virus. IV. Movement protein and coat protein are both essential for cell-to-cell movement of cucumber mosaic virus. Virology 237:237-248.

3. Carrington, J. C., Kasschau, K. D., Mahajan, S. K., and Schaad, M. C. 1996. Cell-to-cell and long distance transport of viruses in plants. Plant Cell 8:1669-1681.

4. Christie, R. G., and Edwardson, J. R. 1977. Light and electron microscopy of plant virus inclusions. Fla. Agric. Exp. Stn. Monogr. No. 9.

5. Diaz-Ruiz, J. R., Kaper, J. M., Waterworth, H. E., and Devergne, J. C. 1979. Isolation and characterization of peanut stunt virus from alfalfa in Spain. Phytopathology 69:504-509.

6. Ding, B., Quibo, L., Nguyen, L., Palukaitis, P., and Lucas, W. J. 1995. Cucumber mosaic virus 3a protein potentiates cell-to-cell trafficking of CMV RNA in tobacco plants. Virology 207:345-353.

7. Ding, S.-W., Anderson, B. J., Haase, H. R., and Symons, R. H. 1994. New overlapping gene encoded by the cucumber mosaic virus genome. Virology 198:593-601.

8. Ghabrial, S. A., Pickard, C. M., and Stuckey, R. E. 1977. Identification and distribution of virus diseases of soybean in Kentucky. Plant Dis. Rep. 61:690-694.

9. Hu, C.-C., Aboul-Ata, A. E., Naidu, R. A., and Ghabrial, S. A. 1997. Evidence for the occurrence of two distinct subgroups of peanut stunt cucumovirus strains: Molecular characterization of RNA3. J. Gen. Virol. 78:929-939.

10. Hu, C.-C., and Ghabrial, S. A. 1998. Molecular evidence that strain BV15 of peanut stunt cucumovirus is a reassortant between subgroup I and II strains. Phytopathology 88:92-97.

11. Hu, C.-C., Sanger, M. P., and Ghabrial, S. A. 1998 . Production of infectious peanut stunt virus RNA from full length cDNA clones representing two subgroups of strains: Mapping satellite RNA support to RNA1. J. Gen. Virol. 79:2013-2021.

12. Iizuka, N., and Yunoki, T. 1974. Peanut stunt virus isolated from soybeans, Glycine max merr. Tohoku Natl. Agric. Exp. Stn. Bull. 49:1-12.

13. Iizuka, N., and Yunoki, T. 1975. Electron microscopy of plant cells infected with legume viruses. Tohoku Natl. Agric. Exp. Stn. Bull. 50:63-86.

14. Kasteel, D. T. J., Wellink, J., Goldbach, R. W., and van Lent, J. W. M. 1997. Isolation and characterization of tubular structures of cowpea mosaic virus. J. Gen. Virol. 78:3167-3170.

15. Kim, J. S., Lee, S. H., and Lee, M. W. 1988. Peanut stunt virus causing mosaic and stunting disease on groundnut in Korea. Korean J. Plant Pathol. 4:88-94.

16. Kraev, V. G., Semerikova, L. I., Vutenko, S. I., and Porembskaya, N. V. 1975. Certain structural changes in cells of host plants induced by peanut stunt virus. Mikrobiol. Zh. Kiev 37:761-764.

17. Martelli, G. P., and Russo, M. 1985. Virus-host relationships: Symptomatological and ultrastructural aspects. Pages 163-205 in: The Plant Viruses, Vol. 1. R. I. B. Francki, ed. Plenum Press, New York.

18. Mink, G. I. 1972. Peanut stunt virus. In: CMI (Commonw. Mycol. Inst.)/ AAB (Assoc. Appl. Biol.) Descriptions of Plant Viruses No. 92.

19. Naidu, R. A., Hu, C.-C., Pennington, R. E., and Ghabrial, S. A. 1995. Differentiation of eastern and western strains of peanut stunt cucumovirus based on satellite RNA support and nucleotide sequence homology. Phytopathology 85:502-507.

20. Newman, G. R. 1989. LR white embedding medium for colloidal gold methods. Pages 47-73 in: Colloidal Gold: Principles, Methods, and Applications. Vol. 2. M. A. Hayat, ed. Academic Press, San Diego, CA.

21. Palukaitis, P., Roossinck, M. J., Dietzgen, R. G., and Francki, R. I. B. 
1992. Cucumber mosaic virus. Adv. Virus Res. 41:281-348.

22. Passmore, B., Sanger, M., Chin, L.-S., Falk, B. W., and Bruening, G. 1993. Beet western yellows virus-associated RNA: An independently replicating RNA that stimulates virus accumulation. Proc. Natl. Acad. Sci. U.S.A. 90:10168-10172.

23. Rybicki, E. P. 1995. Bromoviridae. Pages 450-457 in: Virus Taxonomy: Sixth Report of the International Committee on Taxonomy of Viruses. F. A. Murphy, C. M. Fauquet, D. H. L. Bishop, S. A. Ghabrial, A. W. Jarvis., G. P. Martelli, M. A. Mayo, and M. D. Summers, eds. Springer-
Verlag, New York (Arch. Virol. Suppl. 10).

24. Spurr, A. R. 1969. A low-viscosity epoxy resin embedding medium for electron microscopy. J. Ultrastruct. Res. 26:31-43.

25. Tomenius, K., Clapham, D., and Meshi, T. 1987. Localization by immunogold cytochemistry of the virus encoded $30 \mathrm{~K}$ protein in plasmodesmata of leaves infected with tobacco mosaic virus. Virology 160:363-371.

26. Xu, Z., Barnett, O. W., and Gibson, P. B. 1986. Characterization of peanut stunt virus strains by host reactions, serology, and RNA patterns. Phytopathology 76:390-395. 